\title{
Penerapan Metode Single Exponential Smoothing Dalam Sistem Informasi Perkiraan Penjualan Material Alat Berat Pada PT. Ari Putra Brass
}

\author{
Application of the Single Exponential Smoothing Method in the Information System for \\ Estimating Sales of Heavy Equipment Materials at PT. Ari Putra Brass \\ Nirmala Wilda ${ }^{1}$, Charles Bronson Harahap ${ }^{2}$ \\ ${ }^{1,2,3}$ Program Studi Sistem Informasi,Fakultas Teknik, Universitas Potensi Utama \\ Jl.K.L. Yos Sudarso KM 6.5 Tanjung Mulia- Medan \\ E-mail:nirmalawilda@gmail.com
}

\begin{abstract}
ABSTRAK
PT. Ari Putra Brass Medan adalah perusahaan yang bergerak dalam bidang produksi alat berat. Perusahaan sering mengalami kendala, khususnya masalah Prediksi Penjualan material alat berat untuk periode berikutnya. Masalah tersebut diantaranya adalah dalam Penjualan material alat berat harus berdasarkan persetujuan dari mandor, sebelum ada persetujuan dari mandor maka materil tidak dapat dibeli, sehingga sering terjadi stok material yang kurang dalam proses Penjualan. Bagian administrasi harus memperoleh persetujuan dari bagian inventori untuk melakukan Penjualan material sehingga membutuhkan waktu yang cukup lama dalam pembuatan laporan Penjualan material. Perusahaan juga kesulitan dalam pembuatan laporan prediksi Penjualan material alat berat disebabkan oleh sistem pengolahan data yang masih menggunakan cara semi komputerisasi. Kesalahan pembuatan laporan prediksi Penjualan material alat berat diatas disebabkan oleh sistem pengolahan data yang masih menggunakan cara semi komputerisasi khususnya dalam pembuatan laporan Penjualan material alat berat, dan proses Prediksi peramalan Penjualan material alat berat sehingga tidak efisien karena membutuhkan waktu yang lama dalam proses penentuan prediksi Penjualan material alat berat dan laporan Penjualan material alat berat tidak dapat diperoleh dengan cepat, yang menjadi bahan penelitian penulis adalah data Penjualan material alat berat pada tahun 2015, tahun 2016, tahun 2017, tahun 2018 dan dan tahun 2019.
\end{abstract}

Kata Kunci : Peramalan, Penjualan, Single Exponential Smothing, PHP, Mysql

\section{ABSTRACT}

PT. Ari Putra Brass Medan is a company engaged in the production of heavy equipment. Companies often experience problems, especially the problem of predicting sales of heavy equipment materials for the next period. These problems include the sale of heavy equipment material must be based on the approval of the foreman, before there is approval from the foreman, the material cannot be purchased, so there is often a lack of material stock in the Sales process. The administration department must obtain approval from the inventory department to make material sales so that it takes quite a long time to make a material sales report. The company is also having difficulty in making prediction reports on sales of heavy equipment materials due to the data processing system that still uses semi-computerized methods. Error making prediction reports sales of heavy equipment material above is caused by data processing systems that still use semi-computerized methods, especially in making reports on sales of heavy equipment materials, and the process of predicting sales forecasts of heavy equipment sales so it is inefficient because it takes a long time to determine Sales predictions heavy equipment material and heavy equipment sales reports cannot be obtained quickly, the author's research material is heavy equipment sales data in 2015, 2016, 2017, 2018 and and 2019.

Keywords: Forecasting, Sales, Single Exponential Smothing, PHP, Mysql 


\section{PENDAHULUAN}

Ramalan (forecast) merupakan dugaan atau perkiraan mengenai terjadinya suatu kejadian atau peristiwa di waktu yang akan datang. Ramalan ini sangat berguna dalam berbagai bidang kehidupan, terutama dalam rangka perencanaan untuk mengantisipasi berbagai keadaan yang terjadi pada masa yang akan datang [1]

PT. Ari Putra Brass Medan adalah perusahaan yang bergerak dalam bidang produksi alat berat. Perusahaan sering mengalami kendala, khususnya masalah Prediksi Penjualan material alat berat untuk periode berikutnya. Masalah tersebut diantaranya adalah dalam Penjualan material alat berat harus berdasarkan persetujuan dari mandor, sebelum ada persetujuan dari mandor maka materil tidak dapat dibeli, sehingga sering terjadi stok material yang kurang dalam proses Penjualan. Bagian administrasi harus memperoleh persetujuan dari bagian inventori untuk melakukan Penjualan material sehingga membutuhkan waktu yang cukup lama dalam pembuatan laporan Penjualan material. Perusahaan juga kesulitan dalam pembuatan laporan prediksi Penjualan material alat berat disebabkan oleh sistem pengolahan data yang masih menggunakan cara semi komputerisasi. Kesalahan pembuatan laporan prediksi Penjualan material alat berat diatas disebabkan oleh sistem pengolahan data yang masih menggunakan cara semi komputerisasi khususnya dalam pembuatan laporan Penjualan materialalat berat, dan proses Prediksi peramalan Penjualan material alat berat sehingga tidak efisien karena membutuhkan waktu yang lama dalam proses penentuan prediksi Penjualan material alat berat dan laporan Penjualan material alat berat tidak dapat diperoleh dengan cepat, yang menjadi bahan penelitian penulis adalah data Penjualan material alat berat pada tahun 2015, tahun 2016, tahun 2017, tahun 2018 dan dan tahun 2019.

Perusahaan ini juga menginginkan penambahan laba yang meningkat lebih signifikan akibat dari transaksi Penjualan material alat berat setiap bulannya, sehingga perusahaan ini membutuhkan suatu aplikasi untuk membantu menentukan prediksi barang apa yang harus dibeli ditiap bulannya. Hasil dari suatu peramalan Penjualan material alat berat merupakan pernyataan atau penilaian terhadap kondisi masa depan mengenai Penjualan material alat berat sebagai proyeksi teknis dari permintaan konsumen potensial untuk jangka waktu tertentu. Meskipun demikian hasil perkiraan yang diperoleh mungkin saja tidak sama dengan rencana. Pemanfaatan ramalan Penjualan material alat berat akan digunakan untuk informasi Penjualan material alat berat untuk memprediksi tingkat Penjualan pada hari yang akan datang.

Dengan menerapkan metode Single Exponential Smothing dapat membantu perusahaan dalam mengatasi masalah tersebut diatas. Penerapan Metode Single Exponential Smoothing sangat tepat untuk menyelesaikan permasalahan diatas karena Metode Single Exponential Smoothing digunakan pada peramalan jangka pendek, biasanya hanya 1 bulan ke depan. Model Single Exponential Smoothing mengasumsikan bahwa data berfluktuasi di sekitar nilai mean yang tetap, tanpa trend atau pola pertumbuhan yang merata.[2]

Dengan menerapkan metode Single Exponential Smoothing maka laporan Penjualan material Alat Berat dapat diperoleh dan ditentukan dengan tepat waktu serta menghasilkan profit sesuai dengan target perusahaan.

\section{MetOde PENELITIAN}

1. Analisis Kebutuhan

Penulis melakukan penelitian untuk menentukan target penelitian, dan memilih PT. Ari Putra Brass Medan sebagai objek penelitian. Penulis melakukan analisis data yang dibutuhkan perancangan sistem adalah :

a. Data material.

b. Data harga.

c. Data pelanggan.

d. Data Pelanggan.

e. Data pembayaran. 
f. Data Penjualan .

2. Desain Sistem

Pada tahap desain sistem penulis melakukan proses desain secara umum peramalan Penjualan material alat berat dengan menggunakan metode Single Moving Average pada PT. Ari Putra Brass Medan menggunakan model perancangan Unified Modelling Language yaitu :
a. Use case diagram.
b. Class diagram.
c. Activity diagram.
d. Sequence diagram.

Adapun spesifikasi kebutuhan dari sistem yang akan dibangun adalah sebagai berikut : a.Spesifikasi Perangkat Keras

Spesifikasi perangkat keras yang dibutuhkan adalah:

1) Processor Intel Celeron CPU B815 $1.60 \mathrm{GHz}$

2) $\operatorname{Ram} 4 G B$

3) Hardisk $500 \mathrm{~GB}$

b. Spesifikasi Perangkat Lunak

Adapun spesifikasi perangkat lunak yang dibutuhkan yaitu:

1) Sistem operasi Windows 7

2) Visual Studio 2010

3) Sql Server

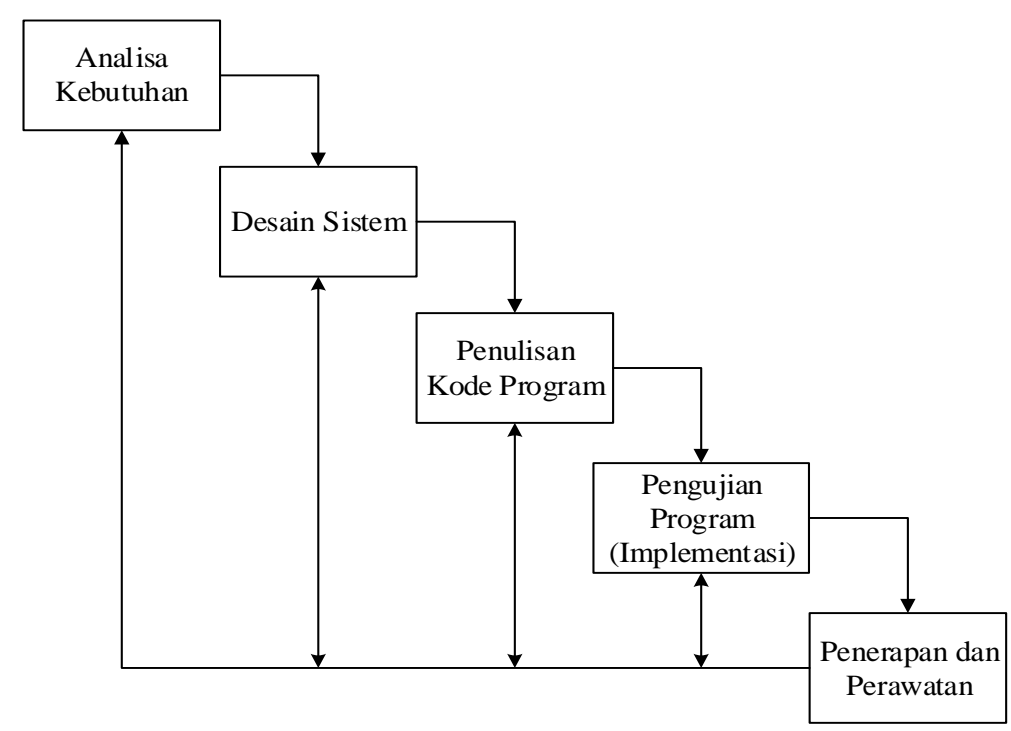

Gambar 1. Kerangka Waterfall

\section{HASIL DAN PEMBAHASAN}

Perusahaan sering mengalami kendala, khususnya masalah Prediksi Penjualan material alat berat untuk periode berikutnya. Masalah tersebut diantaranya adalah dalam Penjualan material alat berat harus berdasarkan persetujuan dari mandor, sebelum ada persetujuan dari mandor maka materil tidak dapat dibeli, sehingga sering terjadi stok material yang kurang dalam proses Penjualan . Bagian administrasi harus memperoleh persetujuan dari bagian inventori untuk melakukan Penjualan material sehingga membutuhkan waktu yang cukup lama dalam pembuatan laporan Penjualan material. Perusahaan juga kesulitan dalam pembuatan laporan prediksi Penjualan material alat berat disebabkan oleh sistem pengolahan data yang masih menggunakan cara semi komputerisasi. Kesalahan pembuatan laporan prediksi Penjualan material alat berat diatas disebabkan oleh sistem pengolahan data yang masih menggunakan cara semi komputerisasi khususnya dalam pembuatan laporan 
Penjualan material alat berat, dan proses Prediksi peramalan Penjualan material alat berat sehingga tidak efisien karena membutuhkan waktu yang lama dalam proses penentuan prediksi Penjualan material alat berat dan laporan Penjualan material alat berat tidak dapat diperoleh dengan cepat, yang menjadi bahan penelitian penulis adalah data Penjualan material alat berat pada tahun 2015, tahun 2016, tahun 2017, tahun 2018 dan dan tahun 2019.

Metode single exponential smoothing mempertimbangkan bobot data-data sebelumnya dengan memberikan bobot pada setiap data periode untuk membedakan prioritas atas suatu data. Rumus untuk Single Exponential Smoothing adalah sebagai berikut:

$\mathrm{Ft}+1=\alpha * \mathrm{Xt}+(1-\alpha) * \mathrm{Ft}$

Keterangan :

$\mathrm{Ft}=$ peramalan untuk periode $\mathrm{t}$

$\alpha \quad=$ konstanta perataan antara 0 dan 1

$\mathrm{Xt}+(1-\alpha) \quad=$ nilai aktual time series

$\mathrm{Ft}+1 \quad=$ peramalan pada waktu $\mathrm{t}+1$

Contoh Kasus

Diketahui data Penjualan Material Alat Berat Pada PT. Ari Putra Brass pada tahun 2019 sebagai berikut :

\begin{tabular}{|c|c|c|}
\hline Bulan & $\begin{array}{c}\text { Jumlah } \\
\text { Penjualan }\end{array}$ & Satuan \\
\hline Januari & 408 & Unit \\
\hline Februari & 398 & Unit \\
\hline Maret & 400 & Unit \\
\hline April & 403 & Unit \\
\hline Mei & 389 & Unit \\
\hline Juni & 401 & Unit \\
\hline Juli & 406 & Unit \\
\hline Agustus & 393 & Unit \\
\hline September & 399 & Unit \\
\hline Oktober & 405 & Unit \\
\hline November & 392 & Unit \\
\hline Desember & 412 & Unit \\
\hline
\end{tabular}

Berikut contoh Prediksi untuk konstanta alpha $(\alpha=0.3) \mathrm{F} 1=$ Karena pada saat $\mathrm{t}=1$ nilai F1 (peramalan pada periode pertama) belum tersedia, maka untuk mengatasi masalah ini dapat dilakukan dengan menetapkan nilai F1 sama dengan nilai data periode pertama (X1) sebesar 33

$$
\begin{aligned}
\mathrm{F} 2 & =\alpha \mathrm{X} 1+(1-\alpha) \mathrm{F} 1 \\
& =(0.3 * 408)+(1-0.3) 408 \\
& =122.4+285.6 \\
& =408 \\
\mathrm{~F} 3 & =\alpha \mathrm{X} 2+(1-\alpha) \mathrm{F} 2 \\
& =(0.3 * 398)+(1-0.3) 408
\end{aligned}
$$


$=119.4+285.6$

$=405$

$\mathrm{F} 4=\alpha \mathrm{X} 3+(1-\alpha) \mathrm{F} 3$

$=(0.3 * 400)+(1-0.3) 405$

$=120+283.5$

$=403.5$

F5 $=\alpha \mathrm{X} 4+(1-\alpha) \mathrm{F} 4$

$=(0.3 * 403)+(1-0.3) 403.5$

$=120.9+282.45$

$=403.35$

$\mathrm{F} 6=\alpha \mathrm{X} 5+(1-\alpha) \mathrm{F} 5$

$=(0.3 * 389)+(1-0.3) 403.35$

$=116.7+282.345$

$=399.045$

$\mathrm{F} 7=\alpha \mathrm{X} 6+(1-\alpha) \mathrm{F} 6$

$=(0.3 * 401)+(1-0.3) 399.045$

$=120.3+279.33$

$=399.63$

$\mathrm{F} 8=\alpha \mathrm{X} 7+(1-\alpha) \mathrm{F} 7$

$=(0.3 * 406)+(1-0.3) 399.63$

$=121.8+279.74$

$=401.54$

F9 $\quad=\alpha \mathrm{X} 8+(1-\alpha) \mathrm{F} 8$

$=(0.3 * 393)+(1-0.3) 401.54$

$=117.9+281.07$

$=398.97$

$\mathrm{F} 10=\alpha \mathrm{X} 9+(1-\alpha) \mathrm{F} 9$

$=(0.3 * 399)+(1-0.3) 398.97$

$=119.7+279.27$

$=398.97$

$\mathrm{F} 11=\alpha \mathrm{X} 10+(1-\alpha) \mathrm{F} 10$

$=(0.3 * 405)+(1-0.3) 398.97$

$=121.5+279.27$

$=400.77$

$\mathrm{F} 12=\alpha \mathrm{X} 11+(1-\alpha) \mathrm{F} 11$

$=(0.3 * 392)+(1-0.3) 400.77$

$=117.6+280.53$ 
$=398.13$

$\mathrm{F} 13=\alpha \mathrm{X} 12+(1-\alpha) \mathrm{F} 12$

$$
\begin{aligned}
& =(0.3 * 412)+(1-0.3) 398.13 \\
& =123.6+278.69 \\
& =402.29
\end{aligned}
$$

Tabel 1. Hasil Peramalan Penjualan

\begin{tabular}{|r|l|r|r|r|c|}
\hline No & Bulan & Data Aktual & Peramalan & et $=$ Xt -Ft & ET $^{2}$ \\
\hline 1 & Januari & 408 & & & \\
\hline 2 & Februari & 398 & 408 & -10 & 100 \\
\hline 3 & Maret & 400 & 405 & -5 & 25 \\
\hline 4 & April & 403 & 403.5 & -0.5 & 0.25 \\
\hline 5 & Mei & 489 & 403.35 & -14.35 & 205.9225 \\
\hline 6 & Juni & 401 & 399.045 & 1.955 & 3.822025 \\
\hline 7 & Juli & 393 & 399.63 & 6.37 & 40.5769 \\
\hline 8 & Agustus & 399 & 398.97 & -8.54 & 72.9316 \\
\hline 9 & September & 405 & 398.97 & 6.03 & 0.0009 \\
\hline 10 & Oktober & 392 & 400.77 & -8.77 & 76.9129 \\
\hline 11 & November & 412 & 398.13 & 13.87 & 192.3769 \\
\hline 12 & Desember & & 402.29 & -402.29 & 161837.2 \\
\hline 13 & Januari & 4806 & 4819.195 & & 162591.4 \\
\hline \multicolumn{2}{|l|}{ Jumlah } & & & & \\
\hline
\end{tabular}

$$
\begin{aligned}
\mathrm{MSE} & =\frac{\sum(\boldsymbol{X} \boldsymbol{t}-\boldsymbol{F t})^{2}}{\boldsymbol{n}} \\
\mathrm{MSE} & =\frac{162591.4}{\mathbf{1 2}} \\
\mathrm{MSE} & =13549.28
\end{aligned}
$$

Pada Prediksi Mean Sequare Error (MSE) untuk alpha 0,3 yaitu memiliki galat error atau nilai kesalahan sebesar 13549.28.

Use case diagram menggambarkan actor, use case dan relasinya sebagai suatu urutan tindakan yang memberikan nilai terukur untuk actor. Sebuah use case digambarkan sebagai elips horizontal dalam suatu diagram UML use case, dapat dilihat pada gambar 2: 


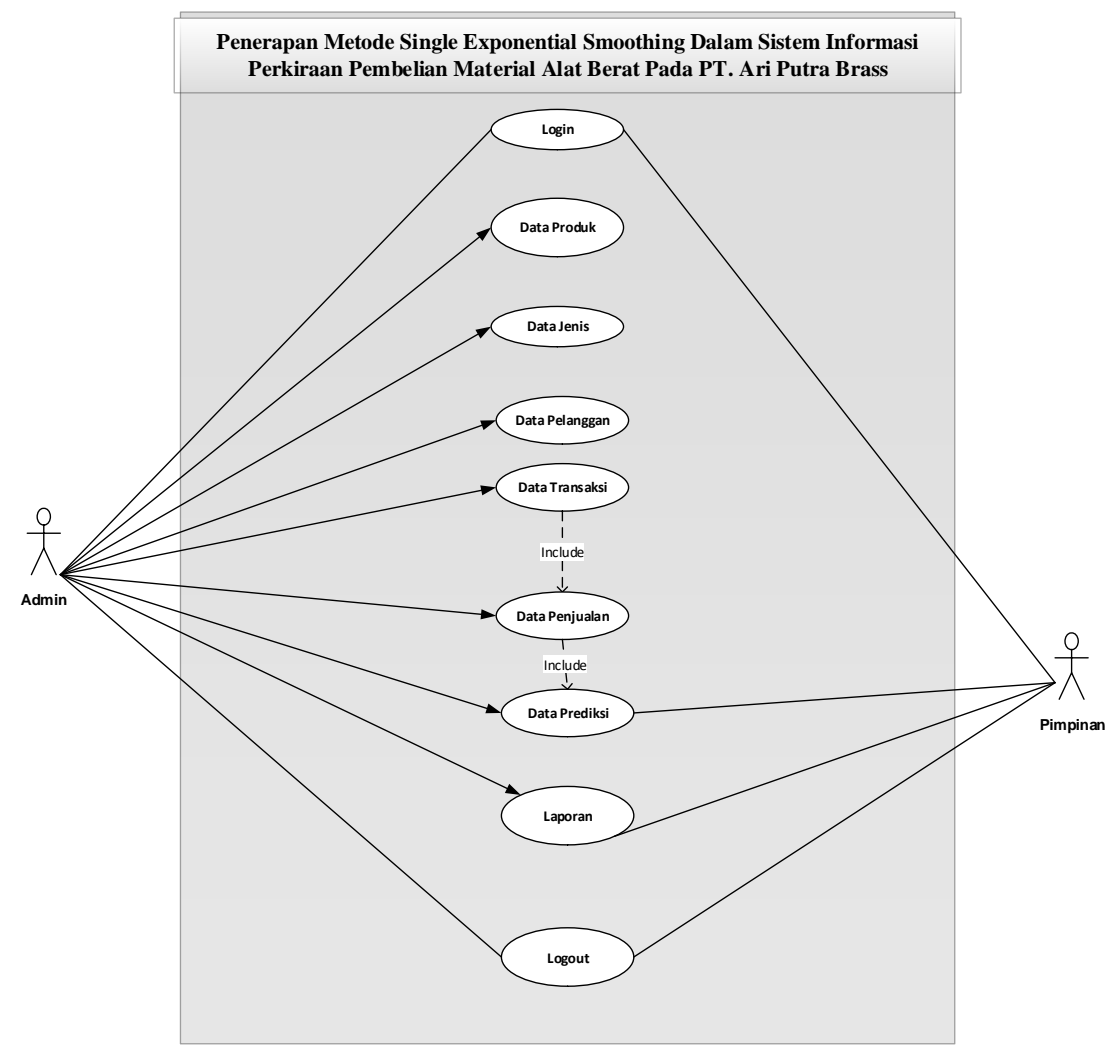

Gambar 2. Use Case Penerapan Metode Single Exponential Smoothing Dalam Sistem

Informasi Perkiraan Penjualan Material Alat Berat Pada PT. Ari Putra Brass

\subsection{Tampilan Hasil}

1. Tampilan Form Data Detail Penjualan

Tampilan ini merupakan tampilan form Data detail Penjualan yang berfungsi untuk mengisi data-data detail Penjualan. Berikut gambar form detail data penjualan ditunjukkan pada 3 :

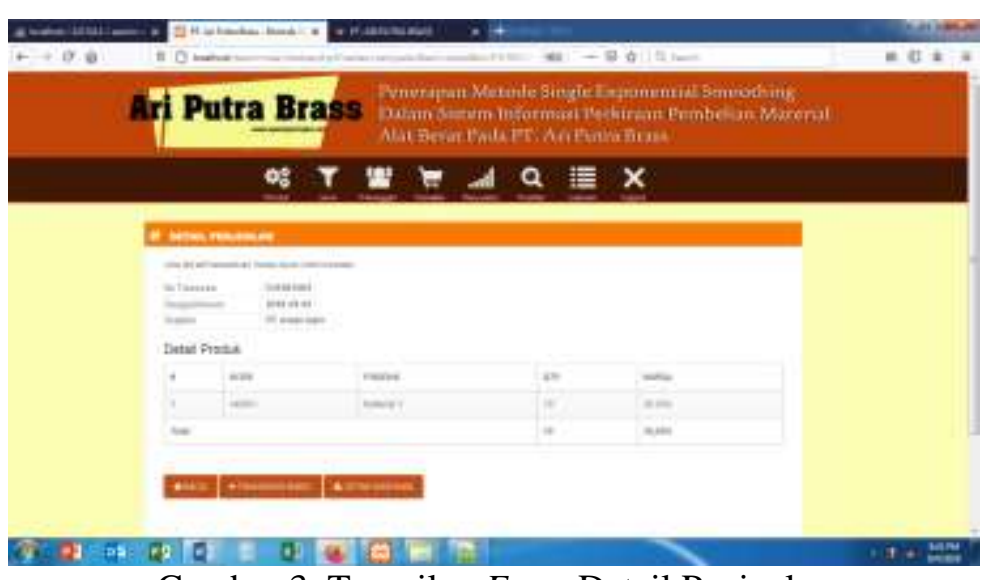

Gambar 3. Tampilan Form Detail Penjualan

2. Tampilan Laporan Penjualan Barang

Tampilan ini merupakan tampilan Laporan Penjualan Barang yang berfungsi untuk mengisi data-data laporan barang Penjualan . Berikut gambar form Laporan Penjalan Barang ditunjukkan pada 4 : 


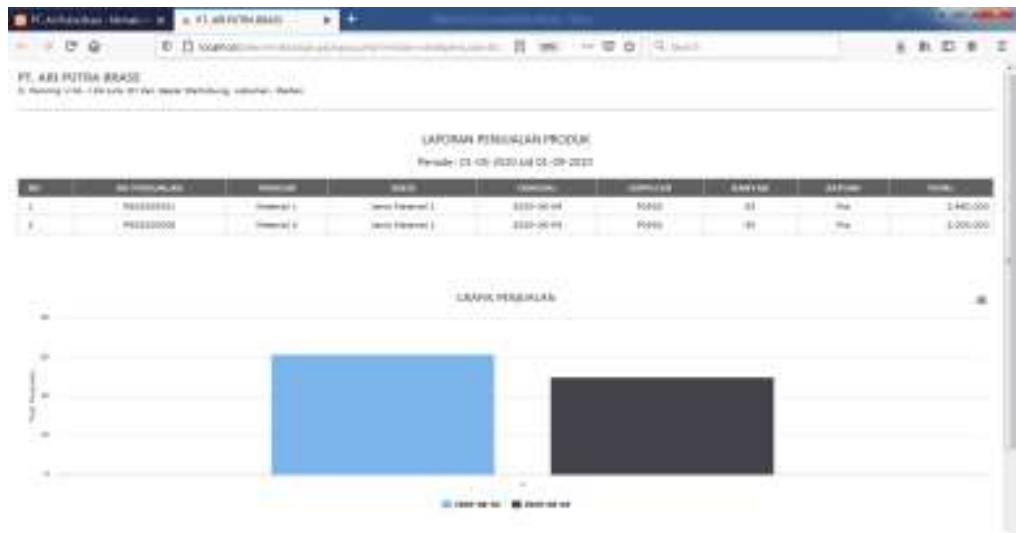

Gambar 4. Tampilan Laporan Penjualan Barang

\section{Tampilan Prediksi}

Tampilan ini merupakan tampilan form Prediksi yang berfungsi untuk mencetak Prediksi. Berikut gambar form Prediksi ditunjukkan pada 5

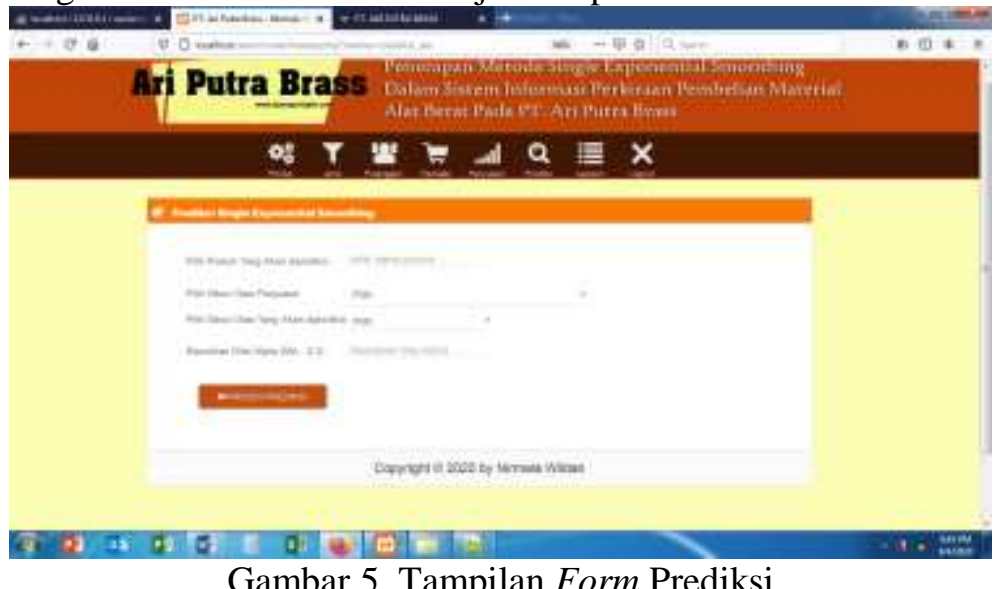

Gambar 5. Tampilan Form Prediksi

\section{Tampilan Hasil Prediksi}

Tampilan ini merupakan tampilan form Prediksi yang berfungsi untuk mencetak Prediksi. Berikut gambar form Prediksi ditunjukkan pada 6:

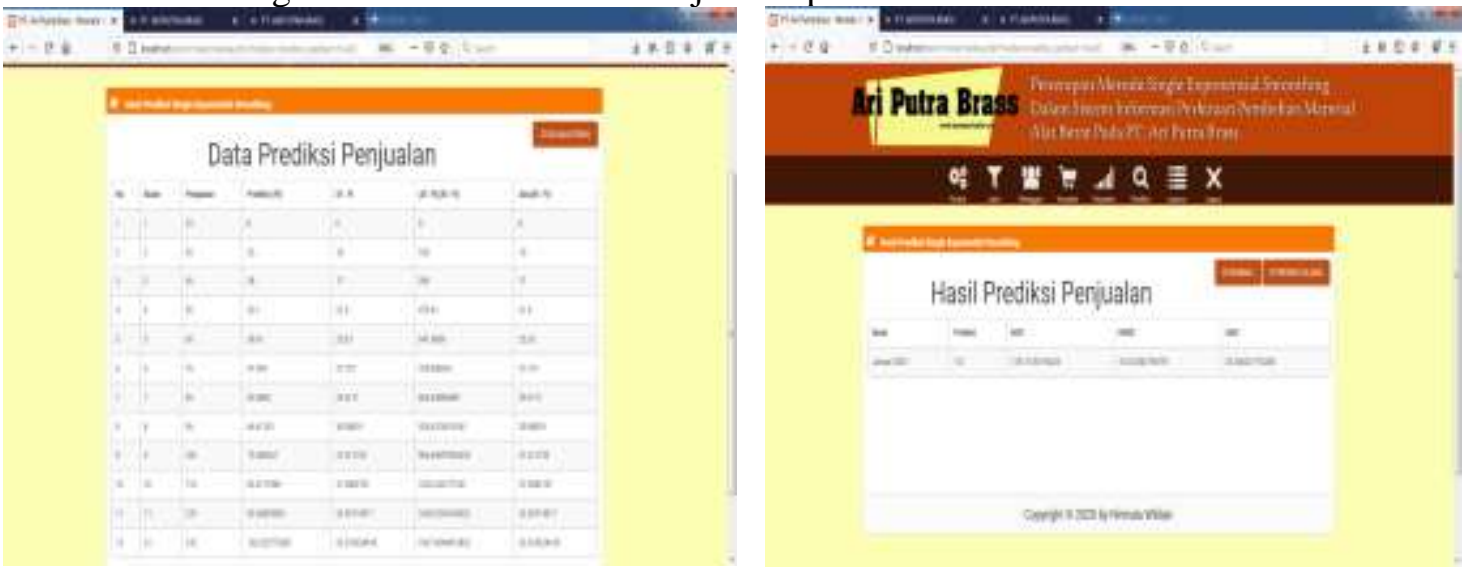

Gambar 6. Tampilan Form Hasil Prediksi

5. Tampilan Laporan Prediksi

Tampilan ini merupakan tampilan form laporan Prediksi yang berfungsi untuk mencetak laporan Prediksi. Berikut gambar form laporan Prediksi ditunjukkan pada 7 : 


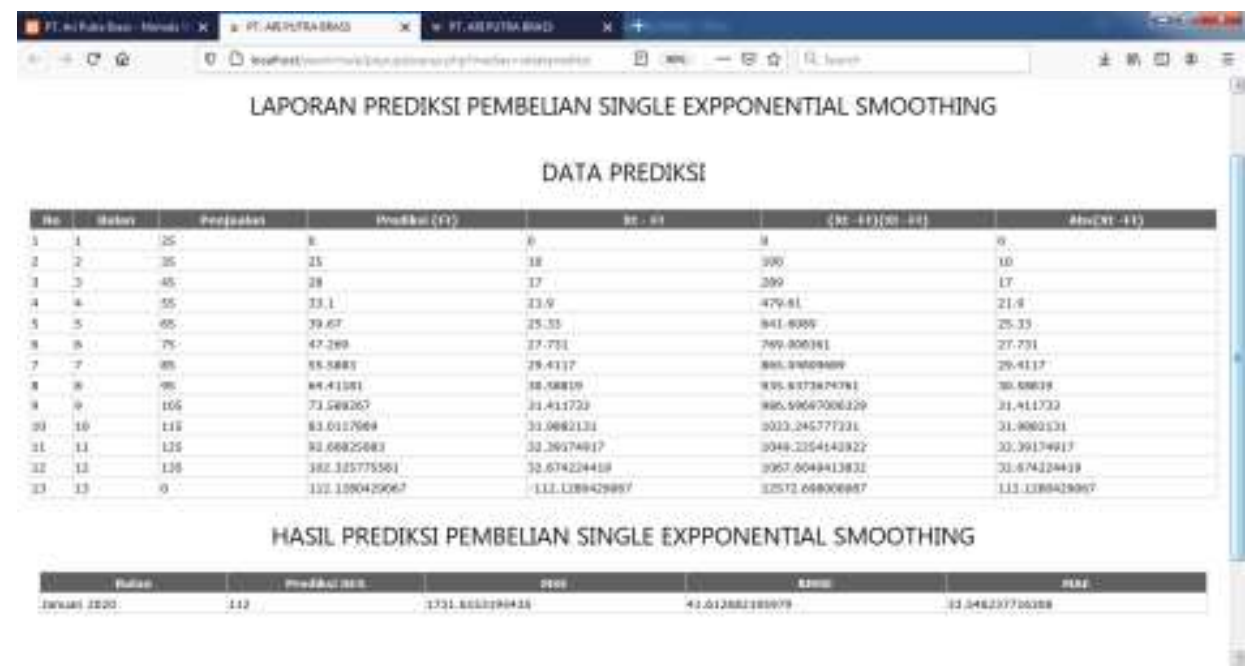

Gambar 7. Tampilan Form Laporan Prediksi

\section{KESIMPULAN}

Dari hasil penelitian penulis, maka dapat diambil beberapa kesimpulan antara lain :

1. Dengan adanya penerapan metode Single Exponential Smoothing dalam menentukan Penjualan material alat berat maka perusahaan akan dengan mudah mengakses informasi-informasi yang diperlukan dalam pengolahan, penginputan maupun dalam pembuatan laporan Penjualan material alat berat.

2. Mengurangi tingkat kesalahan yang terjadi dalam pengolahan, penginputan maupun dalam pembuatan laporan dapat mempermudah dan mempercepat user/ pengguna dalam melakukan pendataan sehingga tidak perlu lagi melakukan pemeriksaan data secara berulang-ulang.

3. Dengan diterapkannya metode Single Exponential Smoothing perusahaan akan mendapatkan keuntungan yang lebih tinggi, karena jumlah stok digudang diprediksi sesuai dengan permintaan.

\section{SARAN}

Adapun saran-saran yang dapat dikemukakan adalah sebagai berikut :

1. Sebaiknya dibangun sebuah sistem yang berbasis online untuk memudahkan perusahaan dalam pembuatan laporan Penjualan material alat berat yang akurat.

2. Sebaiknya dilakukan pengembangan sistem tentang pencatatan Penjualan material alat berat yang lebih efektif.

3. Sebaiknya dilakukan pengembangan sistem yang berbasis client server sehingga proses kinerja dari karyawan bisa mencapai benefit sesuai dengan target perusahaan.

4. Untuk pengembangan sistem selanjutnya diharapkan agar aplikasi yang dirancang dalam peramalan produk sebaiknya dioerkirakan untuk menghitung keseluruhan kategori produk yang terjual secara otomatis.

\section{UCAPAN TERIMA KASIH}

Penulis mengucapkan terima kasih kepada Universitas Potensi Utama yang telah banyak memberikan masukkan dan saran dalam penyelesaian Penelitian ini. 


\section{DAFTAR PUSTAKA}

[1] Setyowati, A. A. (2017). Penerapan Metode Single Exponential Smoothing dan Double Exponential Smoothing Pada Peramalan Penjualan Pakaian. Artikel Skripsi.

[2] Margi, K., \& Pendawa, S. (2015). Analisa dan penerapan metode single exponential smoothing untuk prediksi penjualan pada periode tertentu (studi kasus: Pt. Media Cemara Kreasi). Prosiding SNATIF, 2.

[3] Margi, K., \& Pendawa, S. (2015). Analisa dan penerapan metode single exponential smoothing untuk prediksi penjualan pada periode tertentu (studi kasus: Pt. Media Cemara Kreasi). Prosiding SNATIF, 2.

[4] Okwara, N. K. M. T. (2013). Sistem Peramalan Dan Monitoring Persediaan Obat Di Rspg Cisarua Bogor Dengan Menggunakan Metode Single Exponential Smoothing Dan Reorder Point. J. Ilm. Komput. dan Imformatika, 45-52.

[5] Fachrurrazi, S. (2019). Peramalan Penjualan Obat Menggunakan Metode Single Exponential Smoothing Pada Toko Obat Bintang Geurugok. TECHSI-Jurnal Teknik Informatika, 7(1), 19-30.

[6] Nurlifa, A., \& Kusumadewi, S. (2017). Sistem Peramalan Jumlah Penjualan Menggunakan Metode Moving Average Pada Rumah Jilbab Zaky. INOVTEK Polbeng-Seri Informatika, 2(1), 18-25. 